\title{
Preservation of Conidia of Broccoli Downy Mildew Fungus with Cryogenic Protectants by Freezing at $-80^{\circ} \mathrm{C}$
}

\author{
Mamoru SATOU* and Fumiyoshi Fukumoto*
}

\begin{abstract}
Conidia of the downy mildew fungus (Peronospora parasitica) which is an obligate parasite were well preserved by freezing at $-80^{\circ} \mathrm{C}$ using suitable cryogenic protectants. The germination rate of the conidia which were suspended in distilled water and frozen at $-20^{\circ} \mathrm{C}$ or $-80^{\circ} \mathrm{C}$ was very low compared with the untreated control. However, the germination rates of the conidia suspended in 5\% dimethyl sulfoxide (DMSO) and $5 \%$ skim milk were $74.8 \%$ and $32.8 \%$ of the control, respectively, even after freezing at $-20{ }^{\circ} \mathrm{C}$. On the other hand, in the preparations directly frozen at $-80^{\circ} \mathrm{C}$, the germination rate of the conidia decreased markedly in comparison with that after freezing at $-20^{\circ} \mathrm{C}$. Nevertheless, in the preparations of conidia frozen by the two-step freezing method at $-20^{\circ} \mathrm{C}$ for $24 \mathrm{hr}$ followed by $-80^{\circ} \mathrm{C}$ for $24 \mathrm{hr}$, the germination rate remained the same as that in the preparations frozen only at $-20^{\circ} \mathrm{C}$. During the storage at $-20^{\circ} \mathrm{C}$, the conidia suspended in $5 \%$ DMSO $+5 \%$ skim milk lost their germination ability after one month. The conidia suspensions which were supplemented with $10 \% \mathrm{DMSO}+5 \%$ skim milk or $10 \% \mathrm{DMSO}+$ $10 \%$ skim milk and frozen by the two-step method at $-20^{\circ} \mathrm{C}$ and at $-80^{\circ} \mathrm{C}$, showed a higher germination rate at least up to a period of 12 months. Moreover, these preparations exhibited a high pathogenicity to the broccoli seedlings. Based on these results, it was suggested that the conidia of the broccoli downy mildew fungus treated with protective substances such as $10 \%$ DMSO $+5 \%$ skim milk or $10 \%$ DMSO $+10 \%$ skim milk which were pre-frozen at $-20^{\circ} \mathrm{C}$ for $24 \mathrm{hr}$ followed by $-80^{\circ} \mathrm{C}$ could be well preserved for a long period of time.
\end{abstract}

(Received October 22, 1992)

Key words: Peronospora parasitica, broccoli, preservation, protectant, freezing.

\section{INTRODUCTION}

As obligate parasites such as downy mildew and powdery mildew fungi can not be cultured on artificial media, it is very difficult to handle many races of these fungi at the same time for phylogenic studies. Therefore, obligate parasites, in general, have been maintained on their hosts or preserved by freezing in liquid nitrogen using protective substances such as glycerol and dimethyl sulfoxide (DMSO) ${ }^{6}$. Sporangia of the hop downy mildew fungus, Pseudoperonospora humuli, and those of the vine downy mildew fungus, Plasmopara viticola ${ }^{10}$, and conidia of the tobacco downy mildew fungus, Peronospora tabacina $a^{4}$, were found to be infectious for a period of 12 months during storage in liquid nitrogen. In the same way, the pathogenicity of the sporangia of the cucumber downy mildew fungus, Pseudoperonospora cubensis, and vine downy mildew fungus was maintained for 200 days by freezing at $-20^{\circ} \mathrm{C}^{2}$. As many attempts to culture downy mildew fungi on artificial media ${ }^{3.78}$ have been unsuccessful, most of the obligate parasites are maintained on their plant hosts ${ }^{1,9,11}$. Although phytopathogenic fungi have been effectively preserved in liquid nitrogen, the facilities required for such preservation are expensive. Thus, we examined the possibility of preserving conidia of the broccoli downy mildew fungus, Peronospora

\footnotetext{
* National Research Institute of Vegetables, Ornamental Plants and Tea, Ano, Mie 514-23, Japan 野菜・茶業
} 試験場 
parasitica, in electronically controlled freezers at $-20^{\circ} \mathrm{C}$ or $-80^{\circ} \mathrm{C}$, using several cryogenic protectants instead of liquid nitrogen.

\section{MATERIALS AND METHODS}

Fungal isolate. The broccoli downy mildew fungus, Peronospora parasitica, was isolated from a broccoli plant in the field of Ano, Mie in 1990. The isolate was maintained and propagated on broccoli seedlings.

Preparation of conidia suspensions. Cotyledons of 7-day-old broccoli seedlings were inoculated with conidia of the broccoli downy mildew fungus and incubated in growth cabinets under 5,000 lux at $20^{\circ} \mathrm{C}$. Many conidia were formed on the undersurface of the leaves 7 days after inoculation. Conidia were collected by washing the infected leaves with sterilized distilled water (D.W.). The conidia suspensions were mixed with the solutions of the protective substances to reach the final concentration shown in the Tables. Conidia were suspended in concentrations of more than $10^{4}$ per $1 \mathrm{ml}$ enough to be fully pathogenic to the broccoli seedlings (unpublished observation). Then, $400 \mu 1$ of the conidia suspensions was put into $2 \mathrm{ml}$ plastic screw-capped ampules ( $1 \mathrm{~cm}$ diam., $5 \mathrm{~cm}$ long), and preserved at $-20^{\circ} \mathrm{C}$ or $-80^{\circ} \mathrm{C}$.

In the cases of preservation using powdery substances, the conidia preparations were treated according to the method of Tetsuka and Katsuya ${ }^{10}$. Leaves with conidia were cut into $5 \mathrm{~mm}^{2}$ segments and dredged with agar, skim milk or polyvinyl alcohol powder. These preparations were pre-frozen at $-20^{\circ} \mathrm{C}$ for $24 \mathrm{hr}$ and preserved at $-80^{\circ} \mathrm{C}$. After freezing and thawing, the leaf segments were transferred to centrifuge tubes containing about $1 \mathrm{ml} \mathrm{D} . \mathrm{W}$. Then, they were stirred with a mixer and centrifuged at $3,000 \mathrm{rpm}$ for $3 \mathrm{~min}$ to remove the protective substances. Pellets of conidia were resuspended in D.W. and used for the germination tests.

Conditions of freezing and thawing. Conidia suspensions were placed in a freezer at $-20^{\circ} \mathrm{C}$ or $-80^{\circ} \mathrm{C}$. The preparations of conidia were thawed for $30-40 \mathrm{~min}$ at room temperature (slow thawing) or in water at $40^{\circ} \mathrm{C}$ (rapid thawing). The procedure adopted for the freezing of the conidia suspensions at $-20^{\circ} \mathrm{C}$ followed by $-80^{\circ} \mathrm{C}$ was designated as the two-step freezing method used in this study.

Estimation of survival of conidia. To determine whether conidia were alive, the presence of the germ tube was used as a criterion. The thawed preparations were placed on $1.5 \%$ water agar and incubated at $20^{\circ} \mathrm{C}$ in the dark overnight. More than one hundred conidia in each of the preserved preparations were examined for the germination tests. It was assumed that conidia with a germ tube were alive. Unfrozen preparations suspended in D.W. were used in all the tests as controls. The values of the germination rate of the conidia in the frozen preparations were expressed as a percentage of the unfrozen original control unless otherwise stated. Bursting or deformation of the conidia after freezing and thawing was diagnosed based on the apparent shape of the conidia under an optical microscope.

Pathogenicity test. Pathogenicity of the conidia which had been preserved by freezing to the broccoli seedlings was checked by the development of the symptoms after inoculation. Eight (16 cotyledons) 7-day-old broccoli seedlings was inoculated with eighty $\mu 1$ of the thawed preparations ( $5 \mu 1$ per one cotyledon) and incubated in growth cabinets under 5,000 lux at $20^{\circ} \mathrm{C}$ for 7 days.

\section{RESULTS}

\section{Germination rate and damage sustained by conidia after the freezing and thawing treatment}

The incidence of bursting or deformation of the conidia in the preparations which were suspended in D.W. and frozen at $-20^{\circ} \mathrm{C}$ or $-80^{\circ} \mathrm{C}$ for one hr increased in comparison with the untreated control after thawing. Especially, by freezing at $-80^{\circ} \mathrm{C}$ the bursting or deformation of the conidia were often induced. The percentages of germination of the conidia in these preparations decreased to $5.5 \%$ and $0.0 \%$, respectively, compared with the untreated control. 
Table 1. Effect of various protective substances on the germination ability of conidia immediately after freezing ${ }^{\mathrm{a})}$

\begin{tabular}{lc}
\hline \hline \multicolumn{1}{c}{ Protective substances } & Germination ability (\%) \\
\hline $5 \%$ DMSO & $74.8^{\text {b) }}$ \\
$5 \%$ adonitol & 50.5 \\
$5 \%$ glycerol & 48.2 \\
$5 \%$ sucrose & 44.7 \\
$5 \%$ glucose & 44.6 \\
$5 \%$ sorbitol & 42.9 \\
$5 \%$ skim milk & 32.8 \\
1\% peptone & 19.8 \\
1\% lysine & 13.2 \\
1\% sodium glutamate & 11.9 \\
1\% blue dextran & 11.8 \\
1\% polypeptone & 9.4 \\
1\% tryptone & 7.9 \\
1\% ficoll & 5.6 \\
$5 \%$ polyvinyl alcohol & 4.2 \\
1\% albumin & 1.7 \\
1\% polyvinylpyrrolidone K-30 & 1.3 \\
D.W. & 2.4 \\
\hline
\end{tabular}

a) The preparations of conidia were frozen at $-20^{\circ} \mathrm{C}$ for one $\mathrm{hr}$ and tested subsequently for their germination ability after thawing in water at $40^{\circ} \mathrm{C}$.

b) Numbers represent the percentage of germination of conidia in frozen preparations compared with that of the unfrozen control. The values are means of four experiments.

\section{Effect of thawing temperatures}

After freezing at $-20^{\circ} \mathrm{C}$ for one $\mathrm{hr}$, there was virtually no difference in the germination rate between rapid and slow thawing in the preparations of conidia suspended in D.W. or supplemented with $5 \%$ glycerol $+5 \%$ skim milk (data not shown). Consequently, the preparations for the following examinations were thawed in water at $40^{\circ} \mathrm{C}$.

Effect of various protective substances in the germination rate of conidia during the freezing and thawing treatment

The germination rate of the conidia in the preparations frozen at $-20^{\circ} \mathrm{C}$ in D.W. for one $\mathrm{hr}$ decreased to $2.4 \%$ of the value of the unfrozen original preparation. After the same procedure, the germination rates of the conidia in the preparations supplemented with each $5 \%$ of DMSO, adonitol, glycerol, glucose, sucrose, sorbitol or skim milk were $74.8 \%, 50.5 \%, 48.2 \%, 44.7 \%, 44.6 \%, 42.9 \%$ and $32.8 \%$, respectively. These values were considerably higher than that of the D.W. preparation. Also, the addition of $1 \%$ of peptone, lysine, sodium glutamate, blue dextran, polypeptone, tryptone, ficoll or $5 \%$ polyvinyl alcohol to the preparations produced a slight protective effect. The effect of substances such as $1 \%$ albumin or $1 \%$ polyvinylpyrrolidone $\mathrm{K} \cdot 30$ was negligible (Table 1 ).

Effect of various concentrations of protective substances on the germination rate of conidia during the freezing and thawing treatment

The effect of higher concentrations of substances which showed a protective effect was examined after freezing at $-20^{\circ} \mathrm{C}$ for one $\mathrm{hr}$ and thawing. As shown in Table 2, there was little difference in the germination rate of the conidia between $5 \%$ and $10 \%$ DMSO, the values being $62.4 \%$ and $58.4 \%$ of that unfrozen of the control, respectively. However, the germination rate of the value of the conidia in the preparations supplemented with $20 \%$ DMSO was $38.0 \%$, a value lower than that when $5 \%$ or $10 \%$ DMSO was employed. Similarly, the percentages of germinated conidia decreased with the increase of the concentrations of glycerol. In the cases of glucose and adonitol, there were almost no differences in the protective effect among the concentrations of $5 \%, 10 \%$ and $20 \%$. The addition of $20 \%$ sucrose was more effective than that of $5 \%$ or $10 \%$ sucrose. Consequently, the preparations of conidia supplemented with 
Table 2. Effect of several concentrations of protective substances on the germination ability of conidia immediately after freezing ${ }^{\text {a) }}$

\begin{tabular}{ccccc}
\hline \hline & \multicolumn{4}{c}{ Germination ability (\%) } \\
\cline { 2 - 4 } Protective substances & \multicolumn{4}{c}{ Concentrations of suspensions } \\
\cline { 2 - 4 } & $0 \%$ & $5 \%$ & $10 \%$ & $20 \%$ \\
\hline DMSO & & $62.4^{\text {b) }}$ & 58.4 & 38.0 \\
glycerol & 31.5 & 16.5 & 10.0 \\
glucose & 24.1 & 22.2 & 18.4 \\
adonitol & & 23.4 & 21.1 & 27.0 \\
sucrose & & 16.0 & 20.9 & 27.3 \\
D.W. & 1.3 & & & \\
\hline
\end{tabular}

a) The preparations of conidia were frozen at $-20^{\circ} \mathrm{C}$ for one $\mathrm{hr}$ and tested subsequently for their germination ability after thawing in water at $40^{\circ} \mathrm{C}$.

b) Numbers represent the percentage of germination of conidia in frozen preparations compared with that of the unfrozen control. The values are means of three experiments.

Table 3. Effect of the combination of protective substances on the germination ability of conidia immediately after freezing ${ }^{\text {a) }}$

\begin{tabular}{lc}
\hline \hline \multicolumn{1}{c}{ Protective substances } & Germination ability (\%) \\
\hline 5\% DMSO & $72.8^{\text {b) }}$ \\
5\% DMSO +5\% glucose & 72.9 \\
5\% DMSO +5\% sucrose & 72.7 \\
5\% DMSO +5\% glycerol & 71.7 \\
5\% DMSO +5\% adonitol & 63.8 \\
5\% DMSO +5\% skim milk & 61.9 \\
5\% DMSO + 1\% peptone & 44.2 \\
5\% DMSO+ 1\% sodium glutamate & 31.3 \\
5\% DMSO +1\% lysine & 26.6 \\
D.W. & 1.1 \\
\hline
\end{tabular}

a) The preparations of conidia were frozen at $-20^{\circ} \mathrm{C}$ for one $\mathrm{hr}$ and tested subsequently for their germination ability after thawing in water at $40^{\circ} \mathrm{C}$.

b) Numbers represent the percentage of germination of conidia in frozen preparations compared with that of the unfrozen control. The values are means of three experiments.

$5 \%$ or $10 \%$ DMSO exhibited higher germination rates than those of other protective substances.

Effect of simultaneous addition of protective substances with DMSO on the germination rate of conidia during the freezing and thawing treatment

After freezing at $-20^{\circ} \mathrm{C}$ for one $\mathrm{hr}$ and subsequent thawing, the germination rates of the conidia in the preparations supplemented with $5 \%$ glucose, $5 \%$ sucrose or $5 \%$ glycerol in addition to $5 \%$ DMSO were $72.9 \%, 72.7 \%$ and $71.7 \%$ of the value of the unfrozen original control, respectively (Table 3 ). These results showed that the combination of those substances with 5\% DMSO induced the same rate of germination compared with the single addition of $5 \%$ DMSO $(72.8 \%)$. Also, in the preparations of conidia supplemented with $5 \%$ DMSO $+5 \%$ adonitol or $5 \%$ DMSO $+5 \%$ skim milk, the germination rates of conidia were apparently higher than that of the D.W. preparation, the values being $63.8 \%$ and $61.9 \%$ of that of the unfrozen control, respectively. The values in the preparations with the combination of $1 \%$ peptone, $1 \%$ sodium glutamate or $1 \%$ lysine with $5 \%$ DMSO were low. Thus, a synergistic effect of the combination of various substances with DMSO could not be observed in any of the experiments.

\section{Preservation of conidia by freezing}

The preparations of conidia suspended in several protective substances were preserved at $-20^{\circ} \mathrm{C}$. During one month of storage, the germination rate of the conidia in the preparations containing $5 \%$ 
Table 4. Effect of protective substances on the germination ability of conidia preserved at $-20 \mathrm{C}$

\begin{tabular}{lcccc}
\hline \hline \multirow{2}{*}{ Protective substances } & \multicolumn{4}{c}{ Germination ability (\%) } \\
\cline { 2 - 4 } & \multicolumn{4}{c}{ Period of storage } \\
\cline { 2 - 4 } & $1 \mathrm{hr}$ & 1 month & 3 months & 6 months \\
\hline $5 \%$ DMSO & $90.3^{\mathrm{b})}$ & 3.2 & 0.9 & 0.0 \\
$5 \%$ DMSO+5\% skim milk & 83.5 & 52.8 & 1.0 & 0.0 \\
$5 \%$ DMSO+5\% glucose & 81.2 & 38.8 & 0.0 & \\
$5 \%$ DMSO+1\% sodium glutamate & 65.0 & 4.7 & 0.0 & \\
\hline
\end{tabular}

a) Period of storage after freezing at $-20^{\circ} \mathrm{C}$.

b) Numbers represent the percentage of germination of conidia in frozen preparations compared with that of the unfrozen control. The values are means of two experiments.

Table 5. Effect of freezing time and temperature on the germination ability of conidia immediately after freezing

\begin{tabular}{|c|c|c|c|c|c|}
\hline \multirow{3}{*}{ Protective substances } & \multicolumn{5}{|c|}{ Germination ability (\%) } \\
\hline & \multicolumn{3}{|c|}{ two hr freezing } & \multicolumn{2}{|c|}{$48 \mathrm{hr}$ freezing } \\
\hline & $-20^{\mathrm{B})}$ & $-20 \rightarrow-80^{\mathrm{bl}}$ & $-80^{8)}$ & $-20^{\mathrm{c})}$ & $-20 \rightarrow-80^{\mathrm{d}}$ \\
\hline $5 \%$ DMSO & $33.2^{\mathrm{e}}$ & 4.1 & 0.2 & 22.1 & 16.1 \\
\hline $5 \%$ DMSO $+5 \%$ skim milk & 33.6 & 6.1 & 0.2 & 14.8 & 25.1 \\
\hline $5 \%$ DMSO $+5 \%$ glucose & 33.1 & 2.3 & 0.7 & 12.9 & 5.5 \\
\hline
\end{tabular}

a) The conidia suspensions were frozen at $-20^{\circ} \mathrm{C}$ or $-80^{\circ} \mathrm{C}$ for two $\mathrm{hr}$.

b) The conidia suspensions were frozen at $-20^{\circ} \mathrm{C}$ for one hr followed by $-80^{\circ} \mathrm{C}$ for one hr.

c) The conidia suspensions were frozen at $-20^{\circ} \mathrm{C}$ for $48 \mathrm{hr}$.

d) The conidia suspensions were frozen at $-20^{\circ} \mathrm{C}$ for $24 \mathrm{hr}$ followed by $-80^{\circ} \mathrm{C}$ for $24 \mathrm{hr}$.

e) Numbers represent the percentage of germination of conidia in frozen preparations compared with that of the unfrozen control. The values are means of three experiments.

DMSO $+5 \%$ skim milk was very high (52.8\%), though almost all the conidia lost their germination ability after three months of preservation (Table 4). The addition of $5 \%$ DMSO $+5 \%$ glucose also resulted in a considerable protective effect one month after freezing. Nevertheless, the germination rate of the conidia in the preparations containing $5 \%$ DMSO or $5 \%$ DMSO $+1 \%$ sodium glutamate decreased even after one month of storage at $-20^{\circ} \mathrm{C}$.

As mentioned previously, since we failed to preserve the conidia of the broccoli downy mildew fungus at $-20^{\circ} \mathrm{C}$ for a long period of time, we improved the method in order to obtain high germination rates of the conidia immediately after freezing at $-80^{\circ} \mathrm{C}$.

First, the effect of the temperature was compared among freezing treatments at $-20^{\circ} \mathrm{C}$ or $-80^{\circ} \mathrm{C}$ for two hr, and at $-20^{\circ} \mathrm{C}$ for one hr followed by $-80^{\circ} \mathrm{C}$ for one hr (two hr two-step freezing treatment). As shown in Table 5, by applying the two-step freezing and thawing method, the germination rates of the conidia treated with $5 \%$ DMSO, $5 \%$ DMSO $+5 \%$ skim milk or $5 \%$ DMSO $+5 \%$ glucose decreased markedly, being $4.1 \%, 6.1 \%$ and $2.3 \%$ of the value of the unfrozen control, respectively. The preparations which were frozen at $-80^{\circ} \mathrm{C}$ for two hr and thawed showed much lower values of $0.2 \%, 0.2 \%$ and $0.7 \%$, respectively. These freezing treatments did not make it possible to preserve the materials at $-80^{\circ} \mathrm{C}$ for a long period of time because the germination rate of the conidia decreased markedly compared with the freezing treatment at $-20^{\circ} \mathrm{C}$ for two hr (Table 5). Furthermore, we prolonged the freezing time $(48 \mathrm{hr})$. Based on these results, in the preparations subjected to freezing at $-20^{\circ} \mathrm{C}$ for 24 $\mathrm{hr}$ followed by $-80^{\circ} \mathrm{C}$ for $24 \mathrm{hr}$ ( $48 \mathrm{hr}$ two-step freezing treatment) and thawing, the germination rate of the conidia treated with $5 \%$ DMSO $+5 \%$ skim milk reached a value that was $25.1 \%$ of that of the unfrozen control, for above the $14.8 \%$ value of the freezing treatment at $-20^{\circ} \mathrm{C}$ for $48 \mathrm{hr}$. In the conidia suspensions treated with $5 \%$ DMSO or $5 \%$ DMSO $+5 \%$ glucose, although the germination rates decreased to $16.1 \%$ and $5.5 \%$ of the value of the unfrozen control by the $48 \mathrm{hr}$ two-step freezing treatment, respectively, these values were higher than those recorded in the two hr two-step freezing 
Table 6. Effect of protective substances on the germination ability and pathogenicity of conidia preserved at $-80^{\circ} \mathrm{C}^{\mathrm{a})}$

\begin{tabular}{|c|c|c|c|c|c|c|c|c|}
\hline \multirow{3}{*}{ Protective substances } & \multicolumn{8}{|c|}{ Germination ability $(\%)$ and pathogenicity } \\
\hline & \multicolumn{8}{|c|}{ Period of storage ${ }^{\text {bj }}$} \\
\hline & \multicolumn{2}{|c|}{ l day } & \multicolumn{2}{|c|}{3 months } & \multicolumn{2}{|c|}{6 months } & \multicolumn{2}{|c|}{12 months } \\
\hline $5 \%$ DMSO & $14.1^{\mathrm{c}}$ & $++{ }^{d \prime}$ & 2.1 & - & 2.0 & - & & \\
\hline $5 \%$ DMSO $+5 \%$ skim milk & 7.5 & +++ & 12.9 & + & 10.2 & + & 10.0 & +++ \\
\hline $5 \%$ DMSO $+10 \%$ skim milk & 38.3 & ++ & 11.3 & + & 12.7 & ++ & 3.9 & ++ \\
\hline $10 \%$ DMSO $+5 \%$ skim milk & 53.7 & ++ & 66.4 & +++ & 55.5 & ++ & 47.7 & +++ \\
\hline $10 \%$ DMSO $+10 \%$ skim milk & 40.9 & ++ & 79.1 & $++t$ & 75.8 & + & 46.9 & +++ \\
\hline D.W. & 0.0 & - & 0.0 & - & & & & \\
\hline
\end{tabular}

a) The preparations of conidia were frozen at $-20^{\circ} \mathrm{C}$ for one day followed by $-80^{\circ} \mathrm{C}$.

b) Period of storage after freezing at $-80^{\circ} \mathrm{C}$

c) Numbers represent the percentage of germination of conidia in frozen preparations compared with that of the unfrozen control. The values are means of two experiments.

d) Pathogenicity to broccoli seedlings : +++ (high) $\sim-$ (absent).

Table 7. Effect of the application of powdery substances on the germination ability of conidia preserved at $-80^{\circ} \mathrm{C}^{a)}$

\begin{tabular}{|c|c|c|c|c|}
\hline \multirow{3}{*}{ Protective substances } & \multicolumn{4}{|c|}{ Germination ability (\%) } \\
\hline & \multicolumn{4}{|c|}{ Period of storage ${ }^{b)}$} \\
\hline & 1 day & 1 month & 3 months & 6 months \\
\hline \multicolumn{5}{|l|}{ Powder ${ }^{\mathrm{c}}$} \\
\hline agar & $10.8^{\mathrm{d} \prime}$ & 7.7 & 1.7 & 0.0 \\
\hline skim milk & 1.2 & 2.3 & 15.2 & 1.4 \\
\hline polyvinyl alcohol & 2.8 & 0.0 & 5.3 & 1.1 \\
\hline \multicolumn{5}{|l|}{ Suspension $^{\mathrm{e})}$} \\
\hline $10 \%$ DMSO $+10 \%$ skim milk & 28.3 & 36.8 & 40.8 & 26.5 \\
\hline D.W. & 1.2 & 0.0 & 0.6 & 0.0 \\
\hline
\end{tabular}

a) The preparations of conidia were frozen at $-20^{\circ} \mathrm{C}$ for one day followed by $-80^{\circ} \mathrm{C}$.

b) Period of storage after freezing at $-80^{\circ} \mathrm{C}$.

c) Leaves with conidia were put into ampules containing each protective substance.

d) Numbers represent the percentage of germination of conidia in frozen preparations compared with that of the unfrozen control. The values are means of two experiments.

e) Suspended conidia were collected from a part of the leaves which were tested for the effect of the powdery substances.

treatment (Table 5). These results indicated that the $48 \mathrm{hr}$ two-step freezing treatment make it possible to maintain a high germination rate of conidia. Consequently, the pre-freezing treatment at $-20^{\circ} \mathrm{C}$ for $24 \mathrm{hr}$ was employed to preserve the preparations of conidia at $-80^{\circ} \mathrm{C}$ for a long period of time.

During the storage at $-80^{\circ} \mathrm{C}$, the germination ability of the conidia suspended in $5 \%$ DMSO was lost almost within three months. The conidia in the preparations supplemented with $5 \% \mathrm{DMSO}+5 \%$ skim milk or $5 \% \mathrm{DMSO}+10 \%$ skim milk showed lower germination rates although they were pathogenic to broccoli seedlings after 12 months of storage. On the other hand, the addition of $10 \%$ DMSO $+5 \%$ skim milk or $10 \% \mathrm{DMSO}+10 \%$ skim milk induced a remarkable protective effect, and the germination rates of these preparations were $47.7 \%$ and $46.9 \%$ of the value of the unfrozen control, respectively, suggesting that these values did not decrease appreciably even 12 months after the preservation. The pathogenicity to the broccoli seedlings also remained high (Table 6).

Moreover, we preserved the conidia of the broccoli downy mildew fungus at $-80^{\circ} \mathrm{C}$ by the method of Tetsuka and Katsuya ${ }^{(0)}$ who used agar, skim milk or polyvinyl alcohol powder for the preservation of the hop and vine downy mildew fungi in liquid nitrogen. After six months of storage, the germination rates of the conidia dredged with agar, skim milk or polyvinyl alcohol powder were $0.0 \%, 1.4 \%$ and 
$1.1 \%$, respectively, values which were significantly low as compared with those of preparations with $10 \%$ DMSO $+10 \%$ skim milk (Table 7 ).

\section{DISCUSSION}

It appeared that the conidia experienced damage in their germination ability by freezing when they were not treated with protectants. In particular, the damage of conidia sustained by freezing at $-80^{\circ} \mathrm{C}$ was more serious than at $-20^{\circ} \mathrm{C}$, and resulted in the loss of germination ability. However, by the $48 \mathrm{hr}$ two-step freezing treatment at $-20^{\circ} \mathrm{C}$ followed by $-80^{\circ} \mathrm{C}$ the germination ability of the conidia remained as high as that by freezing at $-20^{\circ} \mathrm{C}$ for $48 \mathrm{hr}$. Moreover, the germination ability of the conidia preserved by the $48 \mathrm{hr}$ two-step freezing treatment sometimes increased compared with freezing at $-20^{\circ} \mathrm{C}$. It appeared that protectants with a high permeability (DMSO and glycerol) and saccharides (adonitol, sucrose, glucose and sorbitol) were effective as protective substances for the preservation of the conidia by freezing (Table 1). Nevertheless, high concentrations of DMSO, glycerol, glucose and adonitol inhibited the germination of the conidia. Basically, the addition of $5 \%$ DMSO or $10 \%$ DMSO played an important role in the maintenance of the high germination ability of the conidia (Table 2). The effect of the speed of thawing of the conidia was less important in relation to germination.

During the preservation by freezing at $-20^{\circ} \mathrm{C}$, the germination rates of the conidia suspended in $5 \%$ DMSO which were the highest immediately after freezing decreased significantly after one month of storage. Also, by the addition of $5 \%$ skim milk or $5 \%$ glucose to $5 \%$ DMSO, the germination rates of the conidia remained high only for one month. Consequently, the storage of the conidia at $-20^{\circ} \mathrm{C}$ was not very effective for a long period of time (Table 4). However, it was suggested that the addition of DMSO+skim milk or DMSO+glucose could possibly improve the preservation of the conidia at ultra-low temperatures for a long period of time.

The germination ability of the conidia which were suspended in DMSO and skim milk and preserved at $-80^{\circ} \mathrm{C}$ after pre-freezing at $-20^{\circ} \mathrm{C}$ remained high for a long period of 12 months. The pathogenicity against the broccoli seedlings was also maintained at a high rate. In particular, since the addition of $10 \%$ DMSO $+5 \%$ skim milk or $10 \% \mathrm{DMSO}+10 \%$ skim milk induced a highly protective effect on both the germination and pathogenicity of the conidia (Table 6), it was suggested that these protectants may be suitable for the preservation of fungi by freezing.

On the other hand, Tetsuka and Katsuya ${ }^{10)}$ described a method for the storage of hop downy mildew fungus, Pseudoperonospora humuli, and vine downy mildew fungus, Plasmopara viticola. In their procedures, the leaflets with conidia were dredged with agar, skim milk or polyvinyl alcohol powder, and preserved in liquid nitrogen. In our experiments, although we preserved the conidia dredged with powdery substances at $-80^{\circ} \mathrm{C}$ instead of using liquid nitrogen, the germination rates of the preparations using these powdery substances decreased markedly during the preservation (Table 7). The storage of conidia suspensions using available protective substances such as $10 \% \mathrm{DMSO}+5 \%$ skim milk, $10 \%$ $\mathrm{DMSO}+10 \%$ skim milk was superior to the method using powdery substances in the case of storage at $-80^{\circ} \mathrm{C}$, and was suitable for the conidia of the broccoli downy mildew fungus ( $P$. parasitica). On the other hand, in the cases of the conidia suspended in D.W. or $5 \%$ skim milk $+0.75 \%$ sodium glutamate that were treated by freeze-drying or liquid-drying ${ }^{6)}$, no germination was observed immediately after these treatments (data not shown). Although Dahmen et al. ${ }^{5)}$ also reported the use of protectants such as skim milk, glycerol and DMSO, etc. for the preservation of phytopathogenic oomycetes fungi such as Phytophthora, Plasmopara and Bremia, they did not apply this method to Peronospora. We developed a method for the preservation of the conidia of the broccoli downy mildew fungus treated with $10 \%$ $\mathrm{DMSO}+5 \%$ skim milk or $10 \% \mathrm{DMSO}+10 \%$ skim milk, which were pre-frozen at $-20^{\circ} \mathrm{C}$ for $24 \mathrm{hr}$ and preserved at $-80^{\circ} \mathrm{C}$. Thus, it is anticipated that our method may make possible easy and economical preservation of broccoli downy mildew fungus for a long period of time, and could be applied to other fungi with similar physiological characteristics such as $P$. parasitica.

The authors wish to thank Dr. T. Ishijima, National Research Institute of Vegetables, Ornamental Plants 
and Tea, for his helpful suggestions and critical reading of the manuscript.

\section{Literature cited}

1. Abd.Elrazik, A.A. and Lorbeer, J.W. (1980). A procedure for isolation and maintenance of Peronospora destructor on onion. Phytopathology $70: 780-782$.

2. Akechi, K. (1983). Storage of sporangia of cucumber and vine downy mildews by freezing. Ann. Phytopath. Soc. Japan 49 : 99 (Abstr. in Japanese).

3. Asada, Y. and Ohguchi, T. (1981). Behavior of downy mildew fungus of Japanese radish on modified Knop's medium. Ann. Phytopath. Soc. Japan $47:$ 71-74.

4. Bromfield, K.R. and Schmitt, C.G. (1967). Cryogenic storage of conidia of Peronospora tabacina. Phytopathology $57: 1133$.

5. Dahmen, H., Staub, Th. and Schwinn, F.J. (1983). Technique for long-term preservation of phytopathogenic fungi in liquid nitrogen. Phytopathology $73: 241-246$.

6. Hamaya, E. (1989). Preservation of plant pathogenic bacteria and fungi. Japanese J. of Freezing and Drying $35: 62-65$.

7. Ohguchi, T. and Asada, Y. (1989). Behavior of downy mildew fungus of Japanese radish on various media. I. Culture from the conidium. Mem. Coll. Agric., Ehime Univ. $33: 189-200$.

8. Ohguchi, T. and Asada, Y. (1989). Behavior of downy mildew fungus of Japanese radish on various media. II. Culture from the infected tissue. Mem. Coll. Agric., Ehime Univ. 33: 201-211.

9. Ohguchi, T., Yoshida, K., Ismail, M.Y. and Asada, Y. (1989). A laboratory method for propagation of downy mildew fungus (Peronospora parasitica) using the cotyledon or true leaf of Japanese radish seedlings. Ann. Phytopath. Soc. Japan $55: 561-566$.

10. Tetsuka, Y. and Katsuya, K. (1983). Storage of sporangia of hop and vine downy mildews in liquid nitrogen. Ann. Phytopath. Soc. Japan $49: 731-735$.

11. Yuen, J.E. and Lorbeer, J.W. (1981). Maintaining Bremia lactucae on washed seedlings of Lactuca sativa in deep petri dishes. Phytopathology $71: 1232-1234$.

\section{和 文 摘 要}

佐藤 衛・福本文良： $-80^{\circ} \mathrm{C}$ の凍結によるブロッコリーベと病菌分生胞子の保存

純寄生菌であるブロッコリーベと病菌 (Peronospora parasitica)の分生胞子を蒸留水に眯濁し, $-20^{\circ} \mathrm{C} て ゙$ 凍結した場 合, 発芽率は無処理に比較して著しく低かった。しかし，5\% dimethyl sulfoxide (DMSO) および $5 \%$ skim milkに

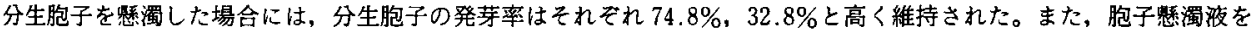
$-80^{\circ} \mathrm{C}$ で直接凍結した場合, 発芽率は著しく低下したが, $-20^{\circ} \mathrm{C} て ゙ 24$ 時間凍結後 $-80^{\circ} \mathrm{C} に$ 移すと, 分生胞子の発芽率

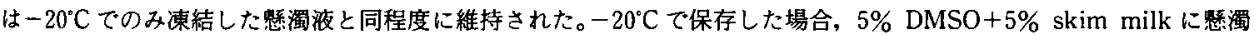
した分生胞子は，わずか 1 か月で発芽力を失った。しかしながら，10\% DMSO+5\% skim milk, 10\% DMSO+10\%

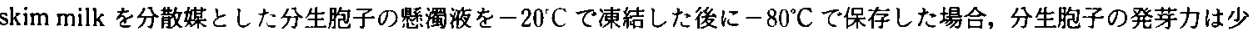
なくとも12 か間高く維持された。これらの分生胞子では、ブロッコリーの子葉に対しても高い病原性が認められた。 これらのことから,ブロッコリーべと病菌の分生胞子は, $10 \%$ DMSO+5\% skim milk または $10 \%$ DMSO+ $10 \%$ skim milk の分散媒に㥎濁したものを $-20^{\circ} \mathrm{C} て ゙$ 予備凍結後 $-80^{\circ} \mathrm{C}$ で東結保存することによって長期保存が可能であること が示唆された。 